\title{
Gender, Myth and Fable: The Perils of Mainstreaming in Sector Bureaucracies
}

\section{Hilary Standing"}

This article is concerned with the ways in which gender and development discourses and frameworks have been appropriated into a particular area of development policy and practice, namely gender mainstreaming efforts in developing country sector bureaucracies. Its origins lie in practical encounters with these efforts while working over the last few years in health sector development programmes in poor countries that are funded by substantial amounts of external aid. It is an attempt to understand why these efforts cause me considerable unease. The myth, in this context, is not a single overarching one. Rather, it is a set of linked mythical assumptions about the nature of social and political transformation and how it is brought about which led to, and became encapsulated in, the practice of gender mainstreaming in bureaucracies. The article also argues that there are fables embedded in some of the common discourses of gender and development. The common thread is an inadequate understanding of the policy domain and how gender and development advocates can engage with it.

Gender mainstreaming in the sector bureaucracies of poor countries has been associated particularly with sector-wide programming in areas such as health and education. Rather than each financing discrete projects, agencies seek to work with governments in a coordinated way to move towards an agreed strategic planning and financial framework with a common funding pool. Progress in embedding gender equity goals in processes such as this depends on building some level of national and local ownership of these objectives (Foster 1999). While clearly in many countries there is advocacy for gender issues from civil society and grassroots organisations, this is much more rarely the case in national and local bureaucracies. This has led to sometimes considerable efforts by donors at developing bureaucratic advocacy for gender goals, mainly through gender training and financing and encouraging institutional means of mainstreaming, particularly gender cells, or the designation of focal points in ministries such as health. Yet a common complaint from gender advocates is that of "policy evaporation" - the tendency for policy commitments to gender equity to be lost, reinterpreted or heavily watered down as they move through (or become mired in) the bureaucracy.

To borrow from anthropology, myths can be good to "think with". For projects of transformation, they offer powerful ways of capturing and framing complex messages in pursuit of desirable outcomes. They can equally be problematic in reducing the complex to the banal and seeming to promise the riches of political change without the long work of politics. As one of the major policy tools with a direct lineage in feminist inspired gender and development, gender mainstreaming in bureaucracies can be an uncomfortable bearer of some of its more mythical thought and practice. The first task is to assemble the mythical elements through an actual event.

\section{The scene}

A workshop is taking place in the Ministry of Health $(\mathrm{MoH})$. We are here to discuss the draft gender equity strategy which three external consultants have been putting together. The $\mathrm{MoH}$ has been under pressure for some time from the donor consortium which funds the health sector programme to incorporate a gender strategy. Consultants have come and gone. There has been commitment and useful input from some of the women's groups and non-governmental 
organisations (NGOs), but no movement within the $\mathrm{MoH}$ itself. Finally, one of the donors brought in the three new gender consultants in a last attempt to move the process forward. I was one of them.

The workshop brought together three sets of actors: staff at various levels in the $\mathrm{MoH}$, donor and international agency representatives and a sprinkling of women's group and other "civil society" representatives.

The external consultants who are facilitating start off, as requested, with an overview of gender analytical frameworks. They have decided to take a low-key, eclectic approach to this task. The staff are from different levels in the hierarchy and have varying competence in English. Most of them are unfamiliar with "gender" language and there is not a readily accessible set of terms in the national language for translating gender concepts. The consultants stress that there is diversity in views and understandings of gender, women, power and powerlessness. They are anxious to avoid prescribing "right" and "wrong" ways of engaging with gender and to encourage the staff in particular to make links with their understanding of the broader programme goals.

The discussion which follows is largely appropriated by donor representatives who are concerned to lay down a correct line on what is gender and how the term should be used. They scold some of the bureaucrats for their "misunderstanding" of gender, particularly in talking about women's health, rather than gender relations. The effect is to confuse and silence the very people who are expected to operationalise the strategy.

\section{What is going on?}

At one level, there is an easy reading of this. The gender and development industry, as epitomised in bureaucratic gender mainstreaming, is a soft target. Here, we have all its less attractive elements. First, there is an agenda driven by outside agencies, often as part of the conditionality for aid. In this case, gender is to a significant extent an externally imposed (and in parts of the bureaucracy resented and not understood) requirement for continuing support. Second, there is capture of language and resources by the particular kinds of elites which the aid industry throws up. Postgraduate and other training programmes in gender and development have produced a new cadre of frequently young, enthusiastic, but barely experienced development professionals who nevertheless occupy influential positions in funding agencies. Third, there is a policing and even shaming of less powerful groups whose discourses do not fit the gender and development hegemony that the dominant voices represent.

At the same time, there is a greater complexity to be addressed here, of which gender mainstreaming in the bureaucracies of subaltern countries is but one important practical manifestation. I feel the need to start from the premise (admittedly a self-serving one in this instance), that all the apparatus which sustains gender mainstreaming - dedicated consultants, training, masters degrees, institutional mechanisms - is not just a massive exercise in bad faith or a way of finding jobs for the girls (although it can certainly turn out that way), that there has been good faith in it and a commitment to gender as a transformative project. So what happened between the passion for social justice which fed the debates, and the reality in many countries of a great deal of official apparatus around gender but massive "policy evaporation" in practice?

I will discuss two interwoven aspects of this. The first is how the project of social transformation became translated into practice in the increasingly professionalised world of gender and development. The second is the way in which the links between theory, policy and practice were rendered relatively unproblematic by naivety about "policy" and how progressive change comes about.

\section{Bureaucracies - drivers or followers of change?}

Sector bureaucracies have become a major focus of mainstreaming efforts in aid-dependent countries. It is not difficult to understand why. Programmes are largely negotiated, designed, managed and monitored by international and national bureaucrats, not by and along with politicians and civil society groups. Of course, the idea is that bureaucracies do this on behalf of these key constituencies. In practice, there may be initial consultation processes (again a condition of aid) which do reach out to other stakeholders, but they rarely go beyond this or develop into sustainable ways in which programme implementers can be brought to account.

The reality in many countries, is that there is often a dearth of institutional and political 
mechanisms through which citizens can have voice and influence or can monitor what governments do (or fail to do) in their name. Instead, influence may be exercised through forms of personal and political patronage and be heavily skewed towards elites. The poor and particularly poor women have little or no access to alternative forms of influence. Bureaucracies are often heavily politicised with officials balancing conflicting demands as they struggle to protect their interests.

Gender mainstreaming in this environment is therefore a paradoxical affair, subject simultaneously to over-politicisation and depoliticisation. It becomes over-politicised when linked to resources to be competed for. It becomes depoliticised as the demand for "industrial" or mass production models of gender mainstreaming in the form of toolkits and checklists grows. This in turn produces a bigger industry of gender professionals, with careers dependent upon a steady demand from development agencies in particular for their services.

These processes lend themselves to easy caricature - a political project becomes reduced to a scramble for study tours and a "tick the box" management of the gender requirements of the programme. There are easy targets for blame opportunistic bureaucrats aware of the possible rewards for talking "gender" and co-option of a previously politically grounded gender advocacy to often apolitical and prescriptive forms of gender training. I would argue, however, that this kind of depoliticisation is largely a consequence of a deeper problem with the way the transformatory project in gender and development came to be understood. As advocates became engaged in translating feminist analysis of gender and development into attempts to influence policy agendas, the site of these efforts shifted increasingly to institutions, and particularly to national bureaucracies. What was lacking was bringing together the theoretical insights of gender and development with an equally sophisticated analysis of institutional roles and functions and how they are linked to or disconnected from the possibilities for change.

Gender mainstreaming in sector bureaucracies is one manifestation of this. It entails a misspecification of the nature, role and functions of bureaucracies. Bureaucracies are not engines of social and political transformation. Indeed, as Orwell, Kafka and others remind us, we need to be ever vigilant that they are not. In this sense, we have cause to be grateful that gender mainstreaming efforts in bureaucracies tend to become depoliticised. Bureaucracy and ideological fervour can make undesirable bedfellows. The appropriate space and place for driving transformation is in the political arena. Mainstreaming objectives which place the onus on a bureaucracy to drive social transformation, especially where the political legitimacy of the institutions of government is already fragile, will therefore continue to run into the hot sands of evaporation. It may also be noted that in the UK we do not expect our bureaucracies to spearhead gender transformation in this way. We simply expect them to do their job.

The role of a health sector bureaucracy is to improve health systems functioning. That was at least understood by the bureaucrats at our workshop, even if the reality falls short of the vision. That was why they persisted in talking about how to improve women's health because the sector programme clearly headlines the health of women and girls as the major strategic objective. But instead of being encouraged in this, they stood accused by the donor representatives of what has become the cardinal sin in this version of mainstreaming namely of "only" meeting women's practical needs rather than their strategic gender interests. What began as a contextually grounded political analysis of different styles of advocacy and became an offthe-peg gender training tool, ended up used as a stick to belabour the bureaucrats with.

What was needed was not a ticking off for focusing on women's health, but a reinforcement of this understanding in terms of enabling the bureaucrats to understand in their own terms the links between improved health systems functioning and "gender equity" and to understand the role they could play. For instance, the major complaints of women about health services are the absence of drugs in the facilities, illicit charges and indifferent and disrespectful treatment by health workers. It is within the remit and capacity of the Ministry of Health to do something about these. If it did, poor women would benefit enormously and there would be knock-on improvements in other areas of their lives. Such objectives are consonant with the primary task of the health system as an organisation and the links to "gender" can be brought out and understood in these terms.

I would argue, therefore, that the main myth in gender mainstreaming in sector bureaucracies is 
not so much a myth of political transformation without politics, but more a mythic relocation of the possibility of political transformation to an inherently non-transformatory context. This mythic relocation requires supporting myths. The first, and most powerful one is that the empowerment language of politics and advocacy can be transferred into bureaucratic mainstreaming without its meaning being changed. Yet institutions always appropriate language and turn it to the service of their own interests. Second, there is the myth of a right and a wrong way to "do" gender in policy contexts; and third, a myth that gender training can produce a desirable and predictable behavioural outcome.

As with all such myths, the relationship to reality is a complex one. There are undoubtedly better and worse ways of "doing" gender, but working out which they are requires a high degree of sensitivity to the context, and a large and often undefinable dollop of wisdom derived from experience. These are often at variance with the pressure for mass production of gender tools and the rapid development of a cadre of trainers. The jury is still out on the value of gender training in bureaucracies. There have been few systematic evaluations. One of the few reviewed training in development partner organisations, not in national bureaucracies (Porter and Smyth 1998). It was equivocal about the impact. Given the demand for training, however, more attention needs to be paid to defining exactly what it is trying to achieve, the contexts in which it is effective and the approaches which are of value.

\section{Naive notions - policy as a route to transformation}

Despite continual challenges from social science, there has been little recognition in gender and development practice of the very problematic link between policy and implementation and the implications of this for social transformation. This is despite the excellent work of individuals writing on constraints to change from an institutional perspective (e.g. Razavi 1997; Kardam 1995).

This naivety towards policy takes a number of forms. First, and linked closely to the bureaucratic mainstreaming model of change already discussed, is the issue of bypassing political processes. Second, is the assumption of a prescriptive and predictable relationship between policy intention and policy outcome. Third, is the tendency to treat discourse and terminology as if they are in themselves independent agents of, or impediments to, change. Let us consider these further.

\subsection{Political bypass}

I have already argued that it is not the role of bureaucracies to transform gender relations and bureaucracies should not be used as a proxy for this. Transformative actions enshrined in progressive policies on gender require political coalitionbuilding, not just a statement on a statute book and a directive to the bureaucracy to carry them out. It follows from this that the apparatus which has been created from professionalising gender and development can play only a modest supporting role in the transformative project. It cannot substitute for the work of politics.

\subsection{Intentions and outcomes}

The complexity and sophistication of gender and development frameworks have not extended to their translation into the policy environment. There has been an almost mechanical belief in the power of intention to determine the outcome of policy implementation. This has generated the myth that policies can be judged on a prior reading of their intent. This is particularly clear in the appropriation of the practical needs/strategic interests distinction to the gender policy toolkit. We have not taken seriously the doctrine of unintended consequences. If we had then we would have understood better the inherently messy and unpredictable nature of this relationship.

In their examination of local economic development projects in a poor urban area of Durban, South Africa, Beall and Todes (2003) give a compelling account of the ways in which carefully crafted "gender sensitive" planning led to unexpected outcomes, partly because women did not simply respond as anticipated and partly because some (well-meant) aspects of project implementation inadvertently damaged women by reinforcing elements of existing social relations and inequalities.

They note that ultimately it was those women who were politicised already, through engagement in earlier political struggles or engaged in local politics, who were able to advance a progressive political and social agenda for women. The technical activities of gender planning were a largely irrelevant sideshow to the political arena. They note also that 
the struggle has been slow, uneven and unpredictable. The experience causes them to question the whole value of externally promoted gender-based planning, particularly in a context where an internally developed politics of transformation already exists.

One important lesson from this is that women are social agents. As agents, they have capacity to subvert intentions, good or bad. This may be by turning paternalism to their advantage or by "refusing" to be progressive if they construe their interests in a different way from the planners. At the same time, policies can also "misbehave": wellintentioned ones can have bad outcomes, and vice versa.

Over-reliance on intention as the arbiter of good and bad policies is linked to an overconfidence that gender and development planning can identify women's interests and devise a pathway to meeting them. This is despite a rich theoretical debate in gender and development on the concept of interests and who is entitled to define them, as well as practical examples that should serve as warnings (Razavi and Miller 1995). For instance, writing on the difficulty of conceptualising women's interests as separate or separable from those of their households, Whitehead (1990) notes that in the context of policies that may increase their household labour burdens, women may feel the trade-off between labour intensification and outcomes is worth it if the outcome advances the interests of the household as a whole. Yet labour intensification occupies a large space in the canon of gender and development "ills".

\subsection{Misbehaving discourses}

The richness of theoretical work in gender and development owes much to discourse analysis, which has unpacked the histories, assumptions and political trajectories of different strands of development thinking in terms of their gender implications. Again, however, this has been to the neglect of an equally rich exploration in the policy domain of the relationship between discourses and outcomes.

We have instead substituted fables for evidencebased assessments. ${ }^{1}$ These are often in the form of binary oppositions. Two particularly tenacious ones are the discourses of equity versus efficiency, and instrumentalism versus equity or advocacy. There has been a great preoccupation with critiquing the development corpus in terms of these discourses, along with exhortations to institutions and actors in the development field to choose the "right" discourse. Much less effort has been expended on understanding how - if at all - these discourses connect to policy implementation in all its complexity.

Instead, we have attached a moral hierarchy to these gender fables, ranking them against each other in a way that abstracts them from their political and social context. Critiques of instrumentalism have been made most strongly on what might be termed absolutist discursive grounds. Instrumentalism is therefore ultimately a "bad" discourse as opposed to equity, which is a "good" one, although we might concede that it is occasionally necessary as a tactic if all else fails. But as with bad stepmothers, bad discourses must be ousted and shamed. Razavi (1997) makes a powerful case against this tendency in her discussion of policy advocacy strategies. She points to the weaknesses of discursive absolutism when faced both with the complex realities of women's and men's lives, and the constraints of working within institutions to try to bring a gender perspective into the policy frame. ${ }^{2}$

Her analysis of gender policy discourses notes the difficulties that gender advocates face when working within institutions on gender issues. There is not only hostility and indifference to the idea of gender itself, but also the everyday political battles and sectional interests which are present in all organisations. Faced with these realities, internal advocates need to use whatever discursive means make sense to fight their corner. She argues that charges of "instrumentalism" from outside are therefore unhelpful. Advocates have to both render their arguments meaningful to an ungendered audience, and do it in a way that makes them more likely to be accepted and acted upon. As Razavi points out, this kind of internal advocacy within institutions is again not an inherently transformative project. It only becomes so when those outside the institution - activists and researchers - can connect it to the political world and to pressures for change. We can add to this that the discursive framing will itself then be transformed by this political connectedness.

Razavi also makes an important plea for using or rejecting discourses on the basis of evidence. Here is one of the key lessons from the history of policy engagement. By no means can all battles for 
gender transformation be won by informed advocacy, but evidence and rational argument remain our most powerful tools in engaging with institutions. This must include interrogating our own discourses and rescuing them where necessary from the realms of the fable.

\section{Concluding reflections}

I have argued that gender mainstreaming in developing country national bureaucracies has been a flawed project based on a myth about how social transformation in gender relations occurs. Associated with this has been an inadequate theorisation of the relationship between theory, policy and implementation and particularly the roles and functions of institutions which set "policy" or mediate its implementation.

Why did some of us, whether as academics, advocates, practitioners or combinations of these, end up understanding mainstreaming and policy in these particular ways? Was it a certain naivety about how real world institutions work? Or was it an inevitable byproduct of professionalising gender and development, particularly in contexts where many of the practitioners do not come from a background in political activism?

There is some truth in both of these. The main route to professionalisation of gender and development has been through academically based courses taught mainly by academics, often with a background in feminist advocacy. This has provided an excellent basis for theoretically rigorous analysis. But we have struggled to carry this forward into the recalcitrant arenas of policy and implementation. We did not make sufficient use of the experience of our students who came from a policy background, nor did we pay enough attention to the skills they would need to go back into those environments and operate more effectively. These skills cannot just be advocacy-based but require a grounding in how institutions work, how to develop contextually-based strategies and create workable alliances in constrained environments.

Instead, the focus of application has been on offthe-peg tools and frameworks, fuelled by the demand for gender mainstreaming. These are not necessarily bad in themselves and I would suggest that the charge of depoliticisation is often misplaced. It is perhaps unavoidable that - in needing to provide an orderly route map for busy people, they exclude context and complexity and become banal and mythic. For instance, one of the results has been a too-automatic privileging of gender relations in practical and policy discourses (Razavi and Miller 1995) to the detriment of other contextually important signifiers of difference and inequality.

What is more troubling is how this industry speaks to power relations through its embeddedness in international aid programmes. The professionalisation of gender and development took place in large measure through the demand from and financial support of development agencies. Most funding of work in gender and development derives from international and bilateral agencies. As bureaucracies themselves, they have led the efforts at mainstreaming. Many of us depend for our livelihoods on doing this work on their behalf. We also need to stand back and examine our practice more critically.

In particular, we need to develop a more situated analysis of the shifting and complex relationships of gender, class, culture, North and South encapsulated in events such as the workshop described above. What are the different sorts of power operating here and who is using or abusing them? How do we begin to think about the dynamics of power in encounters between, for instance young, often female and white, aid bureaucrats and older, often male officials of national bureaucracies?

How far does any of this matter? I think the answer is again a paradoxical one. It matters both a little and a lot. The logic of my argument about bureaucratic mainstreaming is that it matters less than we have tended to think. The apparatus of mainstreaming can at most make a modest contribution to political transformation. It matters a lot in three senses. First, we could do it better by rescuing it from an impossible project to transform gender relations to a more modest adjunct to improving necessary things which can make a difference in women's and men's lives. Second, we could "do" policy much better by paying the same rigorous attention to it as we do to the political economy of gender relations. Third, we need to acknowledge and explore the less obvious power relations which a professionalised gender and development industry has brought into being. 


\section{Notes}

* Thanks to Gerry Bloom for insightful comments on an earlier draft.

\section{References}

Beall, J. and Todes, A., 2003, 'Headlines and headspace: challenging gender planning orthodoxy in area-based urban development', paper prepared for the International Workshop, Feminist Fables and Gender Myths: Repositioning Gender in Development Policy and Practice, Institute of Development Studies, Sussex, 2-4 July

Foster, M., 1999, Lessons of Experience from Health Sector SWAps, London: Centre for Aid and Public Expenditure/Overseas Development Institute (CAPE/ODI)

Kardam, N., 1995, 'Conditions of accountability for gender policy: the organisational, political and cognitive contexts', IDS Bulletin, Vol 26 No 3: $11-22$
1. I use fable in the sense of a story told to convey a lesson, not to represent a body of evidence.

2. See Razavi's (1997) discussion of the dilemmas experienced by gender advisers in the World Bank.

Porter, P. and Smyth, I., 1998, 'Gender training for development policy implementers: only a partial solution', Oxfam Working Paper, Oxford: Oxfam

Razavi, S., 1997, 'Fitting gender into development institutions', World Development, Vol 25 No 7: 1111-25

Razavi, S. and Miller, C., 1995, 'From WID to GAD: conceptual shifts in the women and development discourse', UNRISD/UNDP Occasional Paper 1, Geneva: United Nations Research Institute for Social Development (UNRISD) and New York: United Nations Development Programme (UNDP) Whitehead, A., 1990, 'Rural Women and Food Production in sub-Saharan Africa', in J. Drèze and A.K. Sen (eds), The Political Economy of Hunger, Vol 1: Entitlement and Wellbeing, Oxford: Clarendon Press 